\title{
FACTORS AFFECTING WORKLOAD DISTRIBUTION AMONG ACADEMIC STAFF IN VISCA 1 !
}

\author{
Fatima T. Baliña \\ Farm and Resource Management Institute (FARMI) \\ Leyte State University \\ Visca, Baybay, Leyte
}

and

Vicente A. Quiton

College of Education, Leyte State University

Visca, Baybay, Leyte

\section{ABSTRACT}

The workload distribution of the academic staff was determined and the factors that influence its variability were identified. The ideal perceived workload of academic staff in the academic department was $56 \%$ in instruction, $24 \%$ in research and $17 \%$ in extension, while in the research centers, $32 \%, 43 \%$ and $24 \%$ for instruction, research and extension functions, respectively. The assignment given by the department heads and the number of approved research projects/extension activities handled/implemented by the staff had the most influence on the variability in workload distribution

KEY WORDS: Workload distribution. Academic staff. Variability. Factors affecting workload.

"I Part of the M.S. thesis of the senior author 


\section{INTRODUCTION}

The primary responsibility of academic staff in a college or university is instruction. However, some academic staff assigned in research centers avoid accepting teaching loads or are otherwise selective in the courses they would like to handle. As a result, those assigned in the academic departments are loaded with instructional functions and thus have very limited time for research and extension activities.

During the period of study, the Visayas State College of Agriculture (ViSCA)* had a total faculty members of 263 broken down as follows: 206 or $78.3 \%$ in academic departments, 50 or $19.0 \%$ in various research centers, and 7 or $2.7 \%$ in administrative offices.

This paper presents the workload of the academic staff in ViSCA and the factors affecting its distribution into their teaching, research and extension functions.

\section{METHODOLOGY}

Primary data were gathered using questionnaires, while the secondary data were taken from some offices in the college. A total of 100 academic staff served as respondents of the study which were. classified into three as follows: administrators, researchers, and teaching staff. Frequency counts, means and percentages were used to analyze the data. Correlation analysis was also used to determine relationships among variables: age, number of children, educational attainment, major and minor field, present position, present alary and others.

"ViSCA is now Leyte State University 


\section{RESULTS AND DISCUSSION}

Academic staff who were administrators, in general, had higher average workload compared to those engaged in teaching and research only. This is expected since administrators, who are usually senior staff, also handle either one, two or all of the following functions: instruction, research and extension. Although research and teaching staff had also other functions, the number of workload units cannot be used to surmise that an academic staff member is underloaded because the giving of workload units to a specific. activity does not necessarily reflect the amount of effort exerted in performing a function. For example, a department head/center director is given 5-10 workload units for heading an office. In instruction, a staff handling one undergraduate subject with 35 students is given 3.99 workload units that already includes lesson preparation, checking papers, preparing examinations and others. Thus, it seems that an ordinary academic staff handling only undergraduate courses would find it difficult to acquire more workload units given the conditions stated.

In school year 1996-1997, the average workload of administrators was still higher than research and teaching staff. However, the difference was much smaller compared to SY 1994-1995 and 1995-1996. This was possibly due to the policy mandated in 1996 by the Office of the Vice President for Academic Affairs (OVPAA) requiring all staff with academic ranks in research centers to handle six workload units in teaching.

In relation to the maximum (23) and the minimum (18) workload requirements of academic staff in VISCA, it appears that they are either within or above the workload requirements. 


\section{Workload Distribution Per Function}

The teaching staff had high instruction workload during the first (17.2) and second (14.8) semester but low in research and extension functions. The research staff did not only have more workload units in research (10.1 \& 9.7 for first \& second semester) but also in extension function compared to administrators and teaching staff. However, their instruction and other functions were quite low. On the other hand, the administrators had almost the same workload units in their instruction (9.7 to 11.6) and administrative (9.8-10.1) functions. Findings show that they also had considerable workload units in research and other functions but very minimal in extension. Obviously, those with administrative function has lesser invo1vement in extension because this requires traveling which is often difficult for those who are in administration.

It appears that younger teaching staff had lesser workload units than older ones (Table 1). In the research staff, however, the opposite holds true. Possibly, older staff members handling instruction function are less likely to get involved in many activities. Besides, they may have already acquired higher position that they no longer need any research activities to acquire more points for promotion. The major field of specialization also showed a significant relationship to research workload probably because there are fields of specialization that provide more opportunities for research.

Younger members with few children had more extension workload compared to older staff members. This could be explained by the fact that extension activities involve traveling which usually older staff may not like to do. However, staff members with many small children tend to limit their travel. The extension function had a negative 


\section{Table 1. Correlation matrix showing the relationship between selected variables and workload units of ViSCA staff in performing different functions.}

\begin{tabular}{|c|c|c|c|c|c|c|}
\hline Variables & Instruction & Research & Extension & $\begin{array}{l}\text { Administra- } \\
\text { tion }\end{array}$ & Others & Total \\
\hline Age & $\begin{array}{l}0.14348 \\
(0.1544)\end{array}$ & $\begin{array}{r}-0.26942^{*} \\
(0.0067)\end{array}$ & $\begin{array}{r}-0.31627^{*} \\
(0.0013)\end{array}$ & $\begin{array}{r}0.24557^{\text {kt }} \\
(0.0138)\end{array}$ & $\begin{array}{r}0.19947^{\text {k* }} \\
(0.0466)\end{array}$ & $\begin{array}{l}0.14626 \\
(0.1465)\end{array}$ \\
\hline No. of children & $\begin{array}{l}0.03140 \\
(0.7564)\end{array}$ & $\begin{array}{l}0.08953 \\
(0.3757)\end{array}$ & $\begin{array}{r}-0.2567^{\star \star} \\
(0.0112)\end{array}$ & $\begin{array}{r}0.12320 \\
0.2220 \\
\end{array}$ & $\begin{array}{r}0.21794^{\text {th }} \\
0.0294 \\
\end{array}$ & $\begin{array}{l}0.18898 \\
(0.0597) \\
\end{array}$ \\
\hline $\begin{array}{l}\text { Age of youngest } \\
\text { child }\end{array}$ & & & & $\begin{array}{l}0.01564 \\
(0.8772)\end{array}$ & $\begin{array}{l}0.06720 \\
(0.5065)\end{array}$ & $\begin{array}{l}0.06769 \\
(0.5034)\end{array}$ \\
\hline $\begin{array}{l}\text { Age of oldest } \\
\text { child }\end{array}$ & $\begin{array}{r}0.6995 \\
(0.4892)\end{array}$ & & & $\begin{array}{r}0.12152 \\
(0.2285) \\
\end{array}$ & $\begin{array}{l}0.15609 \\
(0.1210)\end{array}$ & $\begin{array}{l}0.05623 \\
(0.5784)\end{array}$ \\
\hline $\begin{array}{l}\text { Highest } \\
\text { educalional } \\
\text { attainment }\end{array}$ & $\begin{array}{l}-0.06165 \\
(0.5423)\end{array}$ & $\begin{array}{l}0.17933 \\
(0.0742)\end{array}$ & $\begin{array}{l}-0.05283 \\
(0.6017)\end{array}$ & $\begin{array}{l}0.29860^{*} \\
(0.0025)\end{array}$ & $\begin{array}{l}0.28099^{*} \\
(0.0046)\end{array}$ & $\begin{array}{l}0.31184^{*} \\
(0.0016)\end{array}$ \\
\hline $\mathrm{Ma}$ & & 2* & $\begin{array}{l}31^{*} \\
02)\end{array}$ & $\begin{array}{l}0.02400 \\
(0.8127)\end{array}$ & $\begin{array}{l}0.41334^{*} \\
(0.0001)\end{array}$ & $\begin{array}{r}0.23780^{*} \\
(0.0172)\end{array}$ \\
\hline Minor field & $\begin{array}{l}0.24 \\
10.0\end{array}$ & & & $\begin{array}{l}0.46153^{*} \\
(0.0001)\end{array}$ & $\begin{array}{r}0.26009^{*} \\
(0.0090)\end{array}$ & $\begin{array}{r}0.19872^{*} \\
(0.0475)\end{array}$ \\
\hline Prese & $\begin{array}{l}-0.01660 \\
(0.8698)\end{array}$ & & $\begin{array}{l}-0.07428 \\
(0.4627)\end{array}$ & $\begin{array}{l}0.46153^{*} \\
(0.0001)\end{array}$ & $\begin{array}{l}0.30333^{\star} \\
(0.0002)\end{array}$ & $\begin{array}{r}0.38083^{*} \\
0.0001)\end{array}$ \\
\hline $\begin{array}{l}\text { Prese } \\
\text { appoi }\end{array}$ & $\begin{array}{r}-0.06118 \\
(0.5454)\end{array}$ & $\begin{array}{l}366 \\
60) \\
\end{array}$ & $\begin{array}{l}-0.12283 \\
(0.2234) \\
\end{array}$ & $\begin{array}{c}0.47864^{*} \\
(0.0001)\end{array}$ & $\begin{array}{l}0.25024^{*} \\
(0.0120)\end{array}$ & $\begin{array}{r}0.28429^{4} \\
(0.0041)\end{array}$ \\
\hline Prese & $\begin{array}{r}-0.08109 \\
(0.4225)\end{array}$ & $\begin{array}{l}0.06448 \\
(0.5239)\end{array}$ & $\begin{array}{r}0.02187 \\
(0.08290) \\
\end{array}$ & $\begin{array}{r}0.42947^{2} \\
(0.0001)\end{array}$ & $\begin{array}{l}0.31282^{4} \\
(0.0015)\end{array}$ & $\begin{array}{l}0.33471^{*} \\
(0.0007)\end{array}$ \\
\hline $\begin{array}{l}\text { Other sources of } \\
\text { income }\end{array}$ & $\begin{array}{r}-27788^{*} \\
(0.0051)\end{array}$ & $\begin{array}{l}0.07664 \\
(0.4485)\end{array}$ & $\begin{array}{l}0.18256 \\
(0.0691)\end{array}$ & $\begin{array}{l}0.03616 \\
(0.7210)\end{array}$ & $\begin{array}{l}0.00906 \\
(0.9288)\end{array}$ & $\begin{array}{r}-0.11072 \\
(0.2728) \\
\end{array}$ \\
\hline $\begin{array}{l}\text { No. of organiza- } \\
\text { tion involved in }\end{array}$ & $\begin{array}{r}-0.21854^{*} \\
(0.0289)\end{array}$ & $\begin{array}{l}-0.00335 \\
(0.9736)\end{array}$ & $\begin{array}{l}0.06792 \\
(0.5020)\end{array}$ & $\begin{array}{l}0.15706 \\
(0.1186) \\
\end{array}$ & $\begin{array}{l}0.07460 \\
(0.4607)\end{array}$ & $\begin{array}{r}-0.01915 \\
(0.8500)\end{array}$ \\
\hline $\begin{array}{l}\text { Number of } \\
\text { academic staff }\end{array}$ & $\begin{array}{l}0.16611 \\
(0.0986)\end{array}$ & $\begin{array}{l}0.01423 \\
(0.8883)\end{array}$ & $\begin{array}{r}-0.020525^{* t} \\
(0.0405)\end{array}$ & $\begin{array}{l}0.00178 \\
(0.9860)\end{array}$ & $\begin{array}{l}0.05743 \\
(0.5703)\end{array}$ & $\begin{array}{l}0.09277 \\
(0.3586)\end{array}$ \\
\hline $\begin{array}{l}\text { Administrative } \\
\text { position held }\end{array}$ & $\begin{array}{r}-0.24244^{* 4} \\
(0.0151)\end{array}$ & $\begin{array}{l}0.07068 \\
(0.4847)\end{array}$ & $\begin{array}{l}0.05798 \\
(0.5666)\end{array}$ & $\begin{array}{l}0.62033 \\
(0.0001)\end{array}$ & $\begin{array}{r}0.21530^{k t} \\
(0.0315) \\
\end{array}$ & $\begin{array}{l}0.36073 \\
(0.0002)\end{array}$ \\
\hline $\begin{array}{l}\text { No. of years in } \\
\text { ViSCA }\end{array}$ & $\begin{array}{l}-0.05569 \\
(0.5821)\end{array}$ & $\begin{array}{l}0.03621 \\
(0.7206)\end{array}$ & $\begin{array}{l}-0.14774 \\
(0.1424)\end{array}$ & $\begin{array}{r}0.22183^{\text {*t }} \\
(0.0265) \\
\end{array}$ & $\begin{array}{l}0.32474^{*} \\
(0.0010)\end{array}$ & $\begin{array}{l}0.18132 \\
(0.0710)\end{array}$ \\
\hline
\end{tabular}

* $p<.05 ; * * 0<.01$ 
significant correlation with the number of academic staff. Departments or centers with less number of academic staff had more extension workload.

Considering that teaching requires much time and effort, those who were engaged in other activities had more organizations participated in, more administrative positions, but lesser instruction workload. The staff's major and minor fields of specialization had a positive significant correlation with the instruction function. Obviously, the instruction workload is more likely to be high if certain fields of specialization are limited. Besides, one of the major considerations in giving workload assignment for instruction is the staff's major field of specialization.

Academic staff with more administrative workload were older, had higher educational attainment and position, had permanent status, earned high salary, and had stayed in ViSCA for quite a long period of time. All of these factors also showed significant relationship to the workload of staff in performing other functions.

There was also a significant relationship between instruction and research and between extension and administrative functions (Table 2). Academic staff with more workload in instruction had lesser workload in research, extension and administration. Perhaps, those with high instruction workload may have very limited time to do other functions. On the other hand, staff with high research workload also tend to have higher workload in extension considering that in many cases these two functions go together. Meanwhile, those with administrative function tend to have also more workload in other functions. 
Table 2. Correlation analysis showing the relationship among the different functions of academic staff in ViSCA.

\begin{tabular}{|c|c|c|c|c|c|c|}
\hline Functions & Instruction & Research & Extension & $\begin{array}{l}\text { Administra- } \\
\text { tlve }\end{array}$ & Others & Total \\
\hline Instruction & $\begin{array}{r}1.00000 \\
(0.0) \\
\end{array}$ & $\begin{array}{l}-.62442^{k} \\
(0.0001)\end{array}$ & $\begin{array}{r}-0.57549^{\star} \\
(0.0253)\end{array}$ & $\begin{array}{r}-0.22359^{* *} \\
(0.0253)\end{array}$ & $\begin{array}{l}0.11481 \\
(0.2554)\end{array}$ & $\begin{array}{l}0.14184 \\
(0.1592)\end{array}$ \\
\hline Research & $\begin{array}{r}-0.62442^{4} \\
(0.0001)\end{array}$ & $\begin{array}{r}1,00000 \\
\cdot(0.0) \\
\end{array}$ & $\begin{array}{l}0.42837^{*} \\
(0.0001)\end{array}$ & $\begin{array}{r}0.11045 \\
(0.2740) \\
\end{array}$ & $\begin{array}{l}-0.01424 \\
(0.8881) \\
\end{array}$ & $\begin{array}{r}0.23680^{*} \\
(0.0177)\end{array}$ \\
\hline Extension & $\begin{array}{r}-0.57549^{*} \\
(0.0001)\end{array}$ & $\begin{array}{c}0.42837^{*} \\
(0.0001)\end{array}$ & $\begin{array}{r}1.00000 \\
(0.0) \\
\end{array}$ & $\begin{array}{l}0.08276 \\
(0.4130)\end{array}$ & $\begin{array}{l}-0.05550 \\
(0.5834) \\
\end{array}$ & $\begin{array}{l}0.06160 \\
(0.5426)\end{array}$ \\
\hline Administrative & $\begin{array}{r}-0.22359^{\star \star} \\
(0.0253)\end{array}$ & $\begin{array}{l}0.11045 \\
(0.2740)\end{array}$ & $\begin{array}{c}\frac{0.0}{0.0827} \\
(0.4130)\end{array}$ & $\begin{array}{r}1.00000 \\
(0.0)\end{array}$ & $\begin{array}{r}0.25319^{\text {kt }} \\
(0.0110)\end{array}$ & $0.52563^{*}$ \\
\hline Others & $\begin{array}{l}0.11481 \\
(0.2554)\end{array}$ & $\begin{array}{r}-0.01424 \\
(0.8881)\end{array}$ & $\begin{array}{l}0.05550 \\
(0.5834)\end{array}$ & $\begin{array}{r}0.25319^{* *} \\
(0.0110)\end{array}$ & $\begin{array}{r}1.00000 \\
(0.0)\end{array}$ & $\begin{array}{r}0.57112^{k} \\
(0.000)\end{array}$ \\
\hline TOTAL & $\begin{array}{l}0.14184 \\
(0.1592) \\
\end{array}$ & $\begin{array}{l}0.23680 \\
(0.0177)\end{array}$ & $\begin{array}{l}0.06160 \\
(0.5626) \\
\end{array}$ & $\begin{array}{l}0.52563^{\circ} \\
(0.0001)\end{array}$ & $\begin{array}{r}0.5712 \\
(0.0001)\end{array}$ & $\begin{array}{r}1.00000 \\
(0.0) \\
\end{array}$ \\
\hline
\end{tabular}

\section{Ideal Workload of Academic Staff}

The respondents had varied ideal percentage workload (Table 3). Those in the academic departments considered $56 \%, 24 \%$, and $17 \%$ as their ideal percentage mean workload for instruction, research, and extension, respectively. In research centers, their ideal average workload was $32 \%$ in instruction, $43 \%$ in research, and $24 \%$ in extension.

\section{Factors Influencing. Workload Distribution}

The assignment given by the academic department heads $(21 \%)$, number of enrollees/courses offered/laboratory sections (12\%) need of the department $(12 \%)$, field of specialization $(10 \%)$, and number of teaching staff $(9 \%)$ were among the factors influencing the distribution of workload every semester in the academic departments (Table 4). In the research centers, the factors that mostly influenced 
Table 3. Respondents' ideal workload percentage for instruction, research and extension.

\begin{tabular}{|c|c|c|c|c|}
\hline \multirow[b]{2}{*}{ Workload Percentage (\%) } & \multicolumn{2}{|c|}{ Academic } & \multicolumn{2}{|c|}{ Research } \\
\hline & $\mathrm{N}=70^{*}$ & $\%$ & $\mathrm{~N}=18^{*}$ & $\%$ \\
\hline \multicolumn{5}{|l|}{ A. Instruction } \\
\hline 20 and below & 3 & 4 & 7 & 39 \\
\hline $21-40$ & 14 & 20 & 7 & 39 \\
\hline $41-60$ & 30 & 43 & 4 & 22 \\
\hline $61-80$ & 20 & 29 & + & - \\
\hline $81-100$ & 3 & 4 & - & - \\
\hline Sub-Total & 70 & 100 & 18 & 100 \\
\hline Mean: & \multicolumn{2}{|c|}{$56 \%$} & & $32 \%$ \\
\hline B. Research & & 1 & & \\
\hline None & 1 & & - & - \\
\hline 20 and below & 29 & 41 & - & - \\
\hline 21.40 & 39 & 56 & 11 & 61 \\
\hline $41-60$ & 1 & 1 & 7 & 39 \\
\hline Sub-Total & 70 & 100 & 18 & 100 \\
\hline Mean & \multicolumn{2}{|c|}{$24 \%$} & \multicolumn{2}{|r|}{$43 \%$} \\
\hline \multicolumn{5}{|l|}{ C. Extension } \\
\hline None & 1 & 1 & - & - \\
\hline 10 and below & 20 & 29 & 2 & 11 \\
\hline $11-20$ & 32 & 46 & 7 & 39 \\
\hline Above 20 & 17 & 24 & 9 & 50 \\
\hline Sub-Total & 70 & 100 & 18 & 100 \\
\hline Mean: & $17 \%$ & & & $24 \%$ \\
\hline
\end{tabular}

* There were 10 in the academic departments and 2 in the research centers who did not indicate their ideal percentage workload

workload distribution were the number of approved research projects/extension activities, need of the center and the administrative functions of the staff.

\section{Improvement of Workload Distribution}

Faculty members in the academic departments thought it proper to assign teaching load to all academic staff including those in research centers (15\%) (Table 5). Another suggestion is to have a balanced distribution of workload regardless of position or rank $(11 \%)$. 
Table 4. Factors influencing the distribution of workload every semester.

\begin{tabular}{|c|c|c|c|c|}
\hline \multirow[b]{2}{*}{ Factors } & \multicolumn{2}{|c|}{ Academic Dept. } & \multicolumn{2}{|c|}{ Research Centers } \\
\hline & $N=80$ & $\%$ & $N=20$ & $\%$ \\
\hline Assignment given by the dept./center heads & 17 & 21 & 5 & 2 \\
\hline $\begin{array}{l}\text { Number of enroliees/course } \\
\text { offered/lab.section }\end{array}$ & 10 & 12 & 1 & 5 \\
\hline Need of the dept./center & 10 & 12 & 3 & 15 \\
\hline $\begin{array}{l}\text { Educational background/field of } \\
\text { specialization of staff }\end{array}$ & 8 & 10 & - & - \\
\hline Number of teachinglresearch staff & 7 & 9 & 1 & 5 \\
\hline $\begin{array}{l}\begin{array}{l}\text { Number of } \\
\text { projects/extension } \\
\text { implemented }\end{array} \\
\end{array}$ & 4 & 5 & 6 & 30 \\
\hline Inlerest of slaff & 4 & 5 & 1 & 1 \\
\hline Consensus during meetings & 4 & 5 & $\therefore$ & - \\
\hline Administrative functions & 3 & 4 & 2 & 10 \\
\hline Availability of funds for research & - & $\cdots$ & 1 & 5 \\
\hline Not tapped lo teach & - & - & 1 & 5 \\
\hline Others & 6 & 8 & 1 & 5 \\
\hline None & - & - & 1 & 5 \\
\hline No response & 7 & 9 & - & - \\
\hline
\end{tabular}

This suggestion was based on observations that there are some staff occupying higher positions with higher salaries but with light workload. Also suggested was the hiring of either part-time or additional full-time faculty in the academic departments with limited staff $(9 \%)$. Moreover, some felt the need to require all academic staff to perform the trilogy of functions. Others had the same idea but with the premise that more weight should be given to the major function of the staff's major unit. Aside from requiring all academic staff to perform the trilogy of functions, there were those who stressed the need to require a specific workload unit for each function. In doing so, the staff will be guided on the percentage of workload that each one is expected to devote per function. 
Table. 5. Respondent's suggestions to improve the workload distribution of VISCA academic staff.

\begin{tabular}{|c|c|c|c|c|}
\hline \multirow{2}{*}{ Suggestions } & \multicolumn{2}{|c|}{$\begin{array}{l}\text { Academic } \\
\text { Dept. }\end{array}$} & \multicolumn{2}{|c|}{ Research Centers } \\
\hline & $N=80$ & $\%$ & $N=20$ & $\%$ \\
\hline $\begin{array}{l}\text { All academic staff including those in research } \\
\text { centers should be given teaching load }\end{array}$ & 12 & 15 & - & - \\
\hline $\begin{array}{l}\text { There should be balanced distribution of workload } \\
\text { among academic staff regardless of position/rank }\end{array}$ & 9 & 11 & - & - \\
\hline $\begin{array}{l}\text { Hire part-time/additional full-time faculty members } \\
\text { for departments with limited siaff }\end{array}$ & 7 & 9 & - & - \\
\hline $\begin{array}{l}\text { Require all academic staff to perform the trilogy of } \\
\text { function: } \\
\text { - with more weight given to major function of } \\
\text { the staff's major unit } \\
\text { - a specific workload unit should be required } \\
\text { for each of the functions }\end{array}$ & 5 & 5 & 1 & 5 \\
\hline $\begin{array}{l}\text { Distribution of workload should be based on } \\
\text { certain criteria (e.g. expertise, discipline, } \\
\text { commitment, educational qualification, } \\
\text { preferences, interest) }\end{array}$ & 5 & 6 & 3 & 15 \\
\hline $\begin{array}{l}\text { Depariment level planning/consultation with staff } \\
\text { should be done in assigning workload }\end{array}$ & 4 & 5 & 1 & 5 \\
\hline $\begin{array}{l}\text { Strict imposition of } 6 \text { teaching workload units of } \\
\text { academic staff in research centers }\end{array}$ & 4 & 5 & 1 & 5 \\
\hline $\begin{array}{l}\text { Heads of different departments/centers and } \\
\text { appropriate offices (ODI, OVPAA, ODRD) should } \\
\text { assess the performance/properly monitor the } \\
\text { workload assignments of academic staff }\end{array}$ & 3 & 3 & 4 & 20 \\
\hline $\begin{array}{l}\text { There is a need to review/improve the existing } \\
\text { college policies/guidelines on workload } \\
\text { distribution especially on the giving of workload } \\
\text { points by activity }\end{array}$ & 5 & 6 & 2 & 10 \\
\hline Tap the services of affiliate/underload staff & 3 & 3 & 1 & 5 \\
\hline $\begin{array}{l}\text { The administration should support } \\
\text { research/extension actlvities of the college }\end{array}$ & 2 & 2 & & 5 \\
\hline $\begin{array}{l}\text { There should be a realignment of all academic } \\
\text { staff based on their field of specialization }\end{array}$ & 2 & 2 & - & - \\
\hline Others. & 12 & 12 & 5 & 25 \\
\hline No response & 4 & 15 & 3 & 15 \\
\hline
\end{tabular}


Considering that not all academic staff are good in all the three functions, some respondents both in the academic departments and research centers suggested that the distribution of workload should be based on certain criteria such as expertise, discipline, commitment, educational qualification and interest. Meanwhile, there were respondents in research centers and academic departments who expressed the need for the department heads, center directors and other appropriate offices such as ODI, OVPAA, and ODRD to regularly assess the performance and properly monitor the workload assignment of academic staff in order to have a clear grasp on how each academic staff is performing.

\section{CONCLUSION AND RECOMMENDATION}

The administrators had the highest average workload during the first (34) and the second (33) semester of SY 1994-1995 and 19951996, respectively. This was followed by the teaching staff with 25 and 23 workload units while the research staff had an average workload of 22 and 21 units.

The ideal percentage workload of academic staff in the academic departments was $56 \%, 24 \%$ and $17 \%$ in instruction, research and extension, respectively, while in the research centers, they indicated $32 \%, 43 \%, 24 \%$ as their ideal percentage workload distribution in the trilogy of functions.

The factors that mostly influenced the variability in workload distribution in the academic departments were assignments given by the academic department heads $(21 \%)$, number of enrollees/courses offered/laboratory sections $(12 \%)$, need of the department $(12 \%)$, field of specialization $(10 \%)$, and number of teaching staff $(9 \%)$. In the research centers, the factors that mostly influenced the workload 
distribution were the number of approved research projects/extension activities $(30 \%)$, need of the center $(15 \%)$, and the administrative functions of staff $(10 \%)$.

Giving teaching load to all academic staff including those in research centers and letting the department heads, center directors and other appropriate offices such as OVPAA, ODI and ODRD assess the performance and monitor the workload assignment of academic staff were the foremost suggestions given by those in academic departments and research centers in order to improve the workload distribution in ViSCA

Based on the conclusion, the following are recommended:

1. The administration should consider the suggestions and possibly use them as basis to improve the workload distribution of academic staff in ViSCA.

2. In order to attain a more balanced distribution of workload, there is a need for the ViSCA administration to review the existing policies and guidelines on workload distribution with consideration of the appropriate criteria relevant to workload assignment. Moreover, the administration should give necessary rewards for compliance and appropriate sanctions for non-compliance with such policies and guidelines.

\section{LITERATURE CITED}

QUITON, V.A: 1985. Interrelating instruction, extension and research in agricultural schools 'for regional development. Medium 7 (1): 10 \& $26-27$

Annual Report. 1995. Visayas State College of Agriculture, Baybay, Leyte. 


\section{ABOUT THE AUTHOR}

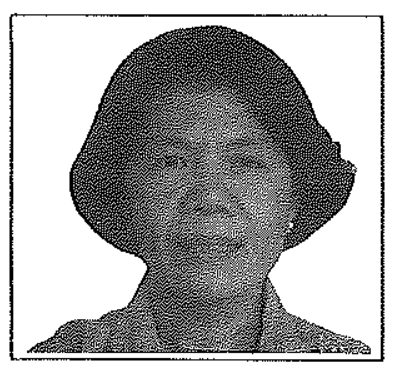

The author finished her Bachelor of Science in Agricultural Education degree in 1982 at the then Visayas State College of Agriculture (VISCA), now the Leyte State University (LSU) as COCOFED scholar.

Immediately after graduation, she worked at the former Department of Agricultural Development Education of LSU as Research Aide and later as Research Assistant until 1984. She transferred to the Farming Systems Development Project-EV (FSDP-EV), now the Farm and Resource Management Institute (FARMI) where she still works as Science Research Assistant.

The co-author is a retired professor of the Department of Science Education of the Leyte State University. 